\title{
Japanese science agencies stress networks in request for budget hike
}

Tokyo. Japan's Science and Technology Agency (STA) and the Ministry of International Trade and Industry (MITI) hope to create a more open government research system through 1995 budget requests submitted to the Ministry of Finance this week. The agencies say their budget plans will encourage closer links between national research institutes, universities and industry.

Both MITI and STA plan to put more money into computer networks that will link government research institutes and universities and to invest in new facilities and programmes to encourage cooperative research between different branches of the government and industry.

Despite a severe squeeze on government finances due to plummeting tax revenues during the recession, both MITI and STA have made ambitious budget requests that are between 8 and 9 per cent more than this year (see table). The requests will be trimmed back in negotiations with the Ministry of Finance before finalization at the end of December.

STA hopes almost to double its spending

\section{Rocket success brings sighs of relief}

Tokyo. Officials of Japan's Science and Technology Agency, who are requesting a large increase in the budget for the agency's space programme (see above), were able to breathe a sigh of relief Sunday (28 August) when Japan's new H-II rocket finally lifted off from the Tanegashima space centre, after two aborted launch attempts (see Nature 370, 586; 1994).

The H-II, which has a sophisticated liquid fuel engine in the first stage similar to that of the US space shuttle, carried a 2tonne test communications satellite. If all goes well, the satellite will move into geostationary orbit after firing its engines three times over the coming weeks.

The new rocket is vital to the agency's future space programme. Most of the proposed increase in the agency's space budget for 1995 will be spent on large Earth observation satellites to be launched by the H-II, and on development of an unmanned space shuttle called HOPE that will be carried on an upgraded version of the rocket. D. S.

\begin{tabular}{|c|c|c|}
\hline$M I T I$ & 1995 & \% change \\
\hline Total $R \& D$ budget request & 307.1 & +7.6 \\
\hline Japan Key Technology Center & 27.0 & +3.8 \\
\hline Industrial Scientific Technology & 25.6 & +8.5 \\
\hline New Sunshine Project & 55.8 & +5.7 \\
\hline Real World Computing Project & 6.0 & +20.9 \\
\hline Intelligent Manufacturing System Project & 1.3 & +1.8 \\
\hline Human Frontier Science Programme & $3.6 *$ & 0.0 \\
\hline Global Environment Research & 13.1 & +9.1 \\
\hline Space Flyer Unit & 8.8 & +5.2 \\
\hline Research Information Center (new) & 0.6 & - \\
\hline NEDO fellows (new) & 0.5 & - \\
\hline \multicolumn{3}{|l|}{ * includes 2.1 billion yen from Science and Technology Agency } \\
\hline Science and Technology Agency & 1995 & $\%$ change \\
\hline Total $R \& D$ budget request & 661.0 & +9.2 \\
\hline Special Promotion Funds & 19.0 & +22.6 \\
\hline Space & 183.7 & +8.7 \\
\hline Nuclear Power & 346.0 & +6.8 \\
\hline ITER & 8.3 & +3.7 \\
\hline Interministry computer network & 2.0 & +81.8 \\
\hline Human Genome & 2.5 & +31.6 \\
\hline SPring-8 & 15.7 & +42.7 \\
\hline Frontier Research System & 3.9 & +19.9 \\
\hline STA Fellowships & 2.2 & +15.8 \\
\hline
\end{tabular}

tional research institutes and from overseas to participate in NEDO projects, including new projects starting next year for the development of computer networks and research information systems.

Traditionally, there has been very little communication between government research organizations belonging to different ministries and agencies because of the bureaucratic walls that separate them. For years the government has been talking about the need for more interaction, but only recently have concrete schemes emerged. If the plans by MITI and STA to establish a more open system are fully realized, this could in the long run revolutionize the way research is carried out and administered in Japan.

MITI has also asked for a 21 per cent increase for its Real World Computing (RWC) project, a 10year initiative by MITI institutes and private industry to develop new massively parallel computers. The

on an interministry computer network now under construction that will link government research institutes and universities via a high-capacity backbone network with access nodes in Tsukuba science city, Tokyo and the Kansai region encompassing Osaka and Kyoto. The agency also requests funds for establishment of several new databases related to the network.

Similarly, MITI has a request of $¥ 600$ million (US\$6 million) for a new centre that will provide users in universities and private industry with access to the ministry's powerful supercomputer centre in Tsukuba science city when they carry out joint research with the ministry's research institutes.

MITI's Agency of Industrial Science and Technology already has a Research Information Processing System (RIPS) that links all 15 of the agency's research institutes around Japan to the supercomputer centre in Tsukuba. But RIPS can be used only by the agency's 2,500 researchers. The aim of the new centre, which will be based in Tsukuba, is to open up the computer system and databases to outside users.

Linked to this initiative is a request to establish a new fellowship scheme to be run by the New Energy and Industrial Technology Development Organization (NEDO), a semi-government organization under the ministry that administers many of MITI's research and development projects. NEDO will support about 60 fellows a year drawn from universities, private companies, na- ministry has requested $¥ 6$ billion for the project next year and plans to invest a total of about $¥ 70$ billion by 2002 .

The project, which began in 1992 on a small budget of $¥ 0.9$ billion, is a follow-up to Japan's famous (but not very successful) fifth-generation computer project. Unlike that project, however, which was carried out in a central laboratory, the RWC project is distributed among numerous laboratories in Japan and one or two in Europe that are (or will be) linked by a high-capacity computer network to allow remote operation of massively parallel systems under development.

The STA, meanwhile, plans to expand the human genome project to $¥ 2.5$ billion, 30 per cent more than this year. The agency's researchers have until now concentrated on mapping of the human genome and the establishment of a gene bank at the Tsukuba Life Science Center of the Institute of Physical and Chemical Research, as well as on the development of sequencing technology. But from next year, the project will move towards full-scale sequencing of the genome, says an agency official.

The human genome project has been one of the driving forces behind the establishment of computer networks in Japan. And human genome researchers should be among the first to benefit from the new interministry network and the hoped-for improvement in links between different branches of the government.

David Swinbanks 